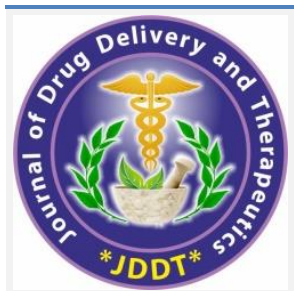

2

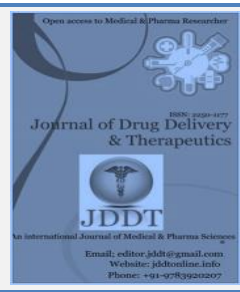

Research Article

\title{
Ethnobotanical Profiling and Floristic Diversity of the Miyawaki Plantation in Saurashtra University Campus, Rajkot
}

\author{
Vijay J. Lagariya and Mital J. Kaneria* \\ Department of Biosciences (UGC-CAS), Saurashtra University, Rajkot-360005, Gujarat, India
}

\section{Article Info:}

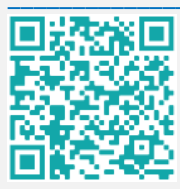

\section{Article History:}

Received 21 Jan 2021;

Review Completed 25 Feb 2021

Accepted 06 March 2021;

Available online 15 March 2021

\section{Cite this article as:}

Lagariya VJ, Kaneria MJ, Ethnobotanical Profiling and Floristic Diversity of the Miyawaki Plantation in Saurashtra University Campus, Rajkot, Journal of

Drug Delivery and Therapeutics. 2021; 11(2):87-99 DOI: http://dx.doi.org/10.22270/jddt.v11i2.4606

\section{Abstract}

The investigation was carried out in order to explore the existing floristic composition of the Miyawaki plantation, recently developed in the Saurashtra University campus, Rajkot. The main aspect of the study is to prepare an ethnobotanical and pharmacological inventory of the recorded plant species from the study area. The fieldwork was conducted for a period of four months regularly in the study area. This study revealed that most of the species as documented are total 71 plant species belonging to 62 genera and 32 families, could be used for the various medicinal purposes from Miyawaki plantation. Present investigation provides a huge lump of ethnobotanical significance and it is an urgent need to document uses of plants for future domestication.

Keywords: Miyawaki, Ethnobotany, Plantation, Floristic diversity, Medicinal plants

\section{*Address for Correspondence:}

Mital J. Kaneria, Department of Biosciences (UGC-CAS), Saurashtra University, Rajkot-360005, Gujarat, India. ORCID ID: https://orcid.org/0000-0003-4498-6003

\section{INTRODUCTION}

Miyawaki plantation method can be simply defined as the random and dense plantation of native plant species of the particular region. This innovative restoration methodology has been extremely successful across the globe to restore the patches of mini forest or pocket forest even in the urban environments. Miyawaki method promotes the process of restoration by planting a dense combination of late and intermediate successional plant species selected on the basis of regional vegetation survey. Native trees of the mini forests grow vigorously, and it is ten times faster and absorbs thirty times more carbon dioxide than those of the natural forest. The technique is introduced by the Japanese botanist Dr. Akira Miyawaki for the development of forest which has several functions but the most important functions are restoration of green environment and ecotechnological (vegetation-ecological approach) reforestation.1-6

Vegetation plays key role in the urban environment by supporting several fundamental subsystems like atmospheric gas balance, biogeochemical cycle, hydrological cycle, climate in the surrounding and others, therefore the development of green area helps to improve the urban environmental conditions. The quality of vegetation in any ecosystem is one of the best indicators of their environmental condition. In addition, the plants have been used for food and medicine since the beginning of human civilization. Use of plants as a source of medicine has been inherited and is an important component of the health care system. Considering the above, the main aim of the present study was to list the plant species present in the Miyawaki plantation at Saurashtra university campus and reveals their medicinal significance.

\section{METHODOLOGY}

Field surveys were conducted continuously during the year 2020-2021 to document the floristic diversity in Miyawaki plantation at Saurashtra University campus, Rajkot. Miyawaki method is the random and dense plantation of the native species. A survey of the vegetation was made and observed different plants such as herbs, shrubs and trees. The identification of plant species during field work was done by using the Flora of Gujarat State 7 , Flora of Presidency of Bombay ${ }^{8}$ and other standard books as well as authenticated by experts. For documentation, the photographs were also taken for selected plant species during the field work. The genera in a family and species in genus are arranged alphabetically. Authenticate literatures were referred to know the ethnobotanical as well as pharmacological significance of the recorded plant species. The plant species includes botanical name, family, common name, vernacular name, life form and medicinal uses.

\section{RESULTS AND DISCUSSION}

List of the plants species recorded in the Miyawaki plantation at Saurashtra University campus are shown along with the botanical information and medicinal uses in Table 1. Floristic enumeration of species in the study area reveals a 
total of 71 species belongs to 62 genera and 32 families (Table $1 \& 2$ ). Analysis of the life form shows that trees predominate with 49 species (69\%) followed by shrubs with 15 species $(21 \%)$, herbs with 6 species $(9 \%)$ and 1 species of grass (1\%) as shown in Figure 1. Of the 32 families found, the first nine families contributing 40 species. Of these Caesalpiniaceae is the most dominant family, comprising 7 species, followed by Apocynaceae 6 spp., Mimosaceae 5 spp., and Moraceae $5 \mathrm{spp}$. (Table 2). The family Combretaceae and Rutaceae are representing 4 species each. Three families are represented by 3 species each, they are Myrtaceae, Papilionaceae and Verbinaceae. The family Acanthaceae, Bignoniaceae, Boraginaceae, Euphorbiaceae, Lamiaceae, Malvaceae, Meliaceae and Sapotaceae are represented by 2 species each and 15 families are only represented by a single species namely Amaranthaceae, Anacardiaceae, Annonaceae, Arecaceae, Bombacaceae, Capparaceae, Crassulaceae, Lythraceae, Moringaceae, Muntingiaceae, Oleaceae, Poaceae, Salvadoraceae, Simaroubaceae and Solanaceae (Table 2). Out of 62 genera Ficus and Terminalia are dominant genera.

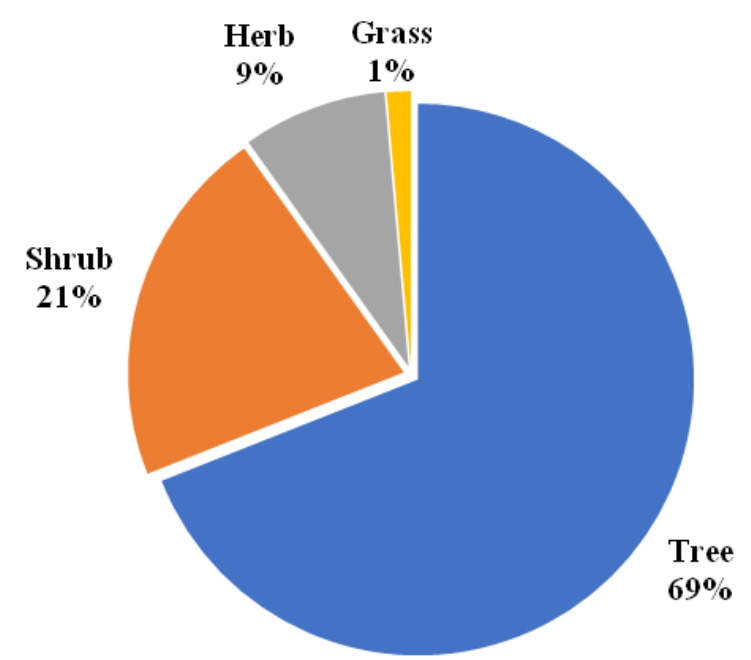

Figure 1: Number of plant form recorded in study area

Table: 1 Information of plant species recorded in study area.

\begin{tabular}{|c|c|c|c|c|c|c|}
\hline No. & Botanical name & Family & $\begin{array}{l}\text { Common } \\
\text { name }\end{array}$ & $\begin{array}{l}\text { Vernacular } \\
\text { name }\end{array}$ & $\begin{array}{l}\text { Life } \\
\text { form }\end{array}$ & $\begin{array}{l}\text { Significance (Ethnobotanical \& } \\
\text { Pharmacological) }\end{array}$ \\
\hline 1 & $\begin{array}{l}\text { Acacia } \\
\text { auriculiformis } \\
\text { A.Cunn. ex Benth. }\end{array}$ & Mimosaceae & $\begin{array}{l}\text { Ear leaf } \\
\text { acacia }\end{array}$ & $\begin{array}{l}\text { Australian } \\
\text { baval }\end{array}$ & Tree & $\begin{array}{l}\text { Extracts of heartwood inhibit fungi that } \\
\text { attack on wood. Used to make an } \\
\text { analgesic by indigenous Australians. }\end{array}$ \\
\hline 2 & $\begin{array}{l}\text { Aegle marmelos } \\
\text { (L.) Correa }\end{array}$ & Rutaceae & Wood apple & Bili & Tree & $\begin{array}{l}\text { Root; fever, abdominal pain, heart } \\
\text { palpitations, urinary troubles, } \\
\text { hypochondriasis, melancholia. Decoction } \\
\text { of Root bark; intermittent fever and as a } \\
\text { constituent in dasamul (ten roots). } \\
\text { Leaves; ophthalmia, deafness, } \\
\text { inflammations. Fresh juice of leaves; } \\
\text { catarrhs and feverishness, eye affections. } \\
\text { Flowers; allaying thirst and vomiting, } \\
\text { dysentery. Unripe fruit, pain, chronic } \\
\text { diarrhoea and dysentery. Ripe fruit; } \\
\text { causes biliousness, cough, heart troubles, } \\
\text { nervous troubles, dypepsia. }\end{array}$ \\
\hline 3 & $\begin{array}{l}\text { Ailanthus excelsa } \\
\text { Roxb. }\end{array}$ & Simaroubaceae & $\begin{array}{l}\text { Indian tree } \\
\text { of heaven }\end{array}$ & Arduso & Tree & $\begin{array}{l}\text { Dyspepsia, bronchitis, dysentery, } \\
\text { diarrhoea, earache, skin diseases, rectum } \\
\text { troubles, allays thirst, removing bad taste } \\
\text { of mouth as tonic. }\end{array}$ \\
\hline 4 & $\begin{array}{l}\text { Albizia lebbeck } \\
\text { (L.) Benth. }\end{array}$ & Mimosaceae & Frywood & Shirish & Tree & $\begin{array}{l}\text { Bark: blood diseases, bronchitis, leprosy, } \\
\text { paralysis, leucoderma, itching, skin } \\
\text { diseases, weakness piles, excessive } \\
\text { perspiration, inflammation, syphilis, } \\
\text { erysipelas, rat-bite, tooth-ache, boils, } \\
\text { scabies. Leaves: asthma, snake-bite, smell } \\
\text { of flower, hemic rania. Seeds: } \\
\text { gonorrhoea, bubesculous glands, piles, } \\
\text { diarrhoea. Seed oil: leucoderma, leprosy. } \\
\text { Gum: inflammation. }\end{array}$ \\
\hline 5 & $\begin{array}{l}\text { Alstonia scholaris } \\
\text { (L.) R.Br. }\end{array}$ & Apocynaceae & Devil's tree & Saptaparni & Tree & $\begin{array}{l}\text { Bark: heart diseases, asthma, } \\
\text { leucoderma, chronic blood diseases, } \\
\text { pains, diarrhoea, advanced stage of } \\
\text { dysentery, leprosy, chronic paludism } \\
\text { with enlargement of spleen, liver } \\
\text { complaints. Milky juice: ulcers, earache. } \\
\text { Tender leaves: in beri-beri, dropsy, } \\
\text { conjested liver, roasted, pulverised and } \\
\text { made into poultices, acts as local } \\
\text { stimulant to unhealthy ulcers, latex } \\
\text { applied to ulcers, tumors and rheumatic }\end{array}$ \\
\hline
\end{tabular}




\begin{tabular}{|c|c|c|c|c|c|c|}
\hline & & & & & & $\begin{array}{l}\text { swelling. Flowers yielding essential oil } \\
\text { and alkaloid picrinine, acts as depressent } \\
\text { on central nervous system. Ash of the } \\
\text { plant is caustic, and is used to open } \\
\text { abscesses. }\end{array}$ \\
\hline 6 & $\begin{array}{l}\text { Alternanthera } \\
\text { dentata (Moench) } \\
\text { Stuchlík ex R. E. } \\
\text { Fr. }\end{array}$ & Amaranthaceae & Little ruby & Lalmendi & Herb & $\begin{array}{l}\text { Used as an antiviral and anti-diarrhoea } \\
\text { agent. }\end{array}$ \\
\hline 7 & $\begin{array}{l}\text { Annona squamosa } \\
\text { L. }\end{array}$ & Annonaceae & $\begin{array}{l}\text { Custard } \\
\text { apple }\end{array}$ & Sitafal & Tree & $\begin{array}{l}\text { Fruit: enriching blood, increasing } \\
\text { muscular strength, burning sensation, } \\
\text { lessening tendency to biliousness, } \\
\text { retrieving vomitting. Seeds: difficult to } \\
\text { digest, causes fever and furunculosis, } \\
\text { produces ulcers in eyes, destroys lice. } \\
\text { Root: dysentery, depression of spirits } \\
\text { and spinal diseases. Crushed leaf: } \\
\text { tympany, bloat, foot and mouth diseases, } \\
\text { dewormer, dressing on wound with } \\
\text { maggots. Leaf juice: in broken horn. }\end{array}$ \\
\hline 8 & $\begin{array}{l}\text { Azadirachta } \\
\text { indica A. Juss. }\end{array}$ & Meliaceae & Neem & Limbdo & Tree & $\begin{array}{l}\text { Bark, vomiting, burning sensation near } \\
\text { the heart, fatigue, fever, thirst, bad taste } \\
\text { in the mouth, cough, cures ulcers, } \\
\text { inflammations, leprosy, blood } \\
\text { complaints, urinary discharges, also } \\
\text { causes loss of appetite. Leaf; Ophthalmia, } \\
\text { biliousness, skin diseases, lessening } \\
\text { inflammation, earache, rheumatism, } \\
\text { symphilitic sores, boils, blood impurities. } \\
\text { Decoction of leaf, Used as a gargle in } \\
\text { stomatitis and for bad gums. Tender } \\
\text { young leaves; eye and skin diseases, } \\
\text { leprosy. Old leaves; in curing ulcers } \\
\text { quickly. Young branches; cough, asthma, } \\
\text { piles, tumours, urinary discharges. Ripe } \\
\text { and unripe fruits; urinary discharges, } \\
\text { skin diseases, tumours, piles, toothache. } \\
\text { Oil of the seed is used to cure skin } \\
\text { diseases. }\end{array}$ \\
\hline 9 & $\begin{array}{l}\text { Bambusa bambos } \\
\text { (L.) Voss }\end{array}$ & Poaceae & Bamboo & Vansh & Grass & $\begin{array}{l}\text { Leaves against menstrual pain and } \\
\text { worms, and to strengthen stomach } \\
\text { function. Root is used for general debility } \\
\text { and joint pain and the plant juice for } \\
\text { osteoarthritis and osteoporosis. }\end{array}$ \\
\hline 10 & $\begin{array}{l}\text { Bauhinia } \\
\text { variegata (L.) } \\
\text { Benth. }\end{array}$ & Caesalpiniaceae & Orchid tree & Kanchnar & Tree & $\begin{array}{l}\text { Bark: Astringent in diarrhoea, root is } \\
\text { carminative and flowers are laxative and } \\
\text { anthelmintic. Decoction of bark is } \\
\text { recommended as useful in ulcers. Bark, } \\
\text { root and flowers mixed with-rice water } \\
\text { are used for boils and abscesses. Paste } \\
\text { made of the bark together with dried } \\
\text { ginger is also applied to scrofulous } \\
\text { tumours. Flowers with sugar are gentle } \\
\text { laxative. The plant is used in malaria and } \\
\text { is also used as an antidote in snake-bite. }\end{array}$ \\
\hline 11 & $\begin{array}{l}\text { Butea } \\
\text { monosperma } \\
\text { (Lam.) Taub. }\end{array}$ & Papilionaceae & $\begin{array}{l}\text { Flame of the } \\
\text { forest }\end{array}$ & Khakhro & Tree & $\begin{array}{l}\text { Leaves and flowers: tonic, astringent, } \\
\text { aphrodisiac, depurgative, diuretic. Leaf } \\
\text { used in eye diseases, in lessening } \\
\text { inflammation and lumbago, curing boils } \\
\text { and piles. Bark: fractures of bones, anus } \\
\text { diseases, piles, dysentery, ulcers and } \\
\text { tumours, lessenin inflammation } \\
\text { biliousness and dysmenorrhoea, liver } \\
\text { disorders, gonorrhoea, purifying blood, } \\
\text { acrid, bitter, oily, appetiser, aphrodisiac, } \\
\text { laxative, anthelmintic. Flowers: cough, }\end{array}$ \\
\hline
\end{tabular}




\begin{tabular}{|c|c|c|c|c|c|c|}
\hline & & & & & & $\begin{array}{l}\text { leprosy, strangury, skin diseases, thirst, } \\
\text { burning sensation, biliousness, } \\
\text { inflammation, burning arine, gonorrhoea. } \\
\text { Juice of Flower: eye diseases, sweet, } \\
\text { bitter, acrid, hot expectorant, } \\
\text { emmengogue. Fruit and seed: urinary } \\
\text { discharges, piles, skin diseases, tumours, } \\
\text { abdominal troubles, scorpion-sting, eye } \\
\text { diseases hot, dry, digestible, } \\
\text { anthelmintic, aperient, bitter oily leaf: } \\
\text { carminative, anthelmintic. Gum: } \\
\text { dysentery, stomatitis, cough, pterygium, } \\
\text { corneal opacities, curing excessive } \\
\text { perspiration, liver tonic, chest and lung } \\
\text { diseases, astringent, aphrodisiac. Root, } \\
\text { curing night blindness and other defects } \\
\text { of sight, elephantiasis. }\end{array}$ \\
\hline 12 & $\begin{array}{l}\text { Caesalpinia } \\
\text { pulcherrima (L.) } \\
\text { Sw. }\end{array}$ & Caesalpiniaceae & $\begin{array}{l}\text { Peacock } \\
\text { flower }\end{array}$ & Galtoro & Shrub & $\begin{array}{l}\text { Flowers: bronchitis, asthma, malarial } \\
\text { fevers. Plant: ulcers, tumours, root and } \\
\text { bulbs: cholera. }\end{array}$ \\
\hline 13 & $\begin{array}{l}\text { Carissa carandas } \\
\text { (L.) Auct. }\end{array}$ & Apocynaceae & $\begin{array}{l}\text { Christ's } \\
\text { thorn }\end{array}$ & Karamda & Shrub & $\begin{array}{l}\text { Fruit: sour, thirst, blood impurities, brain } \\
\text { diseases, diminishes sexual power. } \\
\text { Causes biliousness. }\end{array}$ \\
\hline 14 & $\begin{array}{l}\text { Cascabela } \\
\text { thevetia (L.) } \\
\text { Lippold }\end{array}$ & Apocynaceae & $\begin{array}{l}\text { Yellow } \\
\text { oleander }\end{array}$ & Pili Karen & Tree & $\begin{array}{l}\text { Plant is bitter, pungent, acrid, hot, } \\
\text { andastringent. The bark is bitter and } \\
\text { cathartic, febrifuge. The milkyjuice of the } \\
\text { tree is poisonous. The leaves are } \\
\text { purgative andemetic. The seeds are } \\
\text { abortifacient, alexiteric and purgative. } \\
\text { The plant is useful in bowels, urethral } \\
\text { discharges, worms, skin diseases, } \\
\text { Leucoderma, wounds, piles, eye troubles, } \\
\text { itching, fevers, bronchitis and cures } \\
\text { "vata". The bark is useful in various } \\
\text { kindsof intermittent fevers. The roots are } \\
\text { made into a plaster and applied to } \\
\text { tumors. }\end{array}$ \\
\hline 15 & Cassia fistula $\mathrm{L}$. & Caesalpiniaceae & $\begin{array}{l}\text { Golden } \\
\text { shower tree }\end{array}$ & Garmalo & Tree & $\begin{array}{l}\text { Pustules, rheumatism, fever, heart- } \\
\text { diseases, retained excretions, bronchitis, } \\
\text { biliousness, ringworm. }\end{array}$ \\
\hline 16 & $\begin{array}{l}\text { Catharanthus } \\
\text { roseus } \\
\text { (L.) G.Don }\end{array}$ & Apocynaceae & Periwinkle & Barmasi & Herb & $\begin{array}{l}\text { Decoction of dried plant, boiled in oil is } \\
\text { rubbed in joint regions in cases of } \\
\text { lumbago. Leaf infusion is administered in } \\
\text { menorrhagia, applied in wasp sting. } \\
\text { Leaves are used in diabetes. Leaves kept } \\
\text { in water in night and the water drunk in } \\
\text { the morning, bring down the sugar level } \\
\text { to normal. }\end{array}$ \\
\hline 17 & $\begin{array}{l}\text { Ceiba pentandra } \\
\text { (L.) Gaertn. }\end{array}$ & Bombacaceae & Kapok tree & Shimlo & Tree & $\begin{array}{l}\text { Used in dysentery, anemia, } \\
\text { inflammatory, dropsial affection, hepatic } \\
\text { disorder, rheumatic and gouty } \\
\text { complaints, Kala-azar, chronic peritoneal } \\
\text { conditions, heart diseases and kidney } \\
\text { ailments. The root juice is used in } \\
\text { diabetes. }\end{array}$ \\
\hline 18 & $\begin{array}{l}\text { Cestrum } \\
\text { nocturnum L. }\end{array}$ & Solanaceae & $\begin{array}{l}\text { Night } \\
\text { blooming } \\
\text { jasmine }\end{array}$ & Raat rani & Shrub & $\begin{array}{l}\text { Decoctions of the dried leaves were not } \\
\text { effective against pharmacologically } \\
\text { induced convulsions, but repeated } \\
\text { administration reduced the amplitude of } \\
\text { epileptic spikes in both primary and } \\
\text { secondary foci. Results suggest the plant } \\
\text { possesses analgesic activity through a } \\
\text { peripheral mechanism. An extract of the } \\
\text { plant is used as an antispasmodic and as } \\
\text { a treatment for epilepsy. In laboratory }\end{array}$ \\
\hline
\end{tabular}




\begin{tabular}{|c|c|c|c|c|c|c|}
\hline & & & & & & $\begin{array}{l}\text { tests, extracts of the plant were shown to } \\
\text { inhibit tumor growth and prolong the } \\
\text { lifetime in a dose-dependent manner. }\end{array}$ \\
\hline 19 & $\begin{array}{l}\text { Citrus limon (L.) } \\
\text { Osbeck }\end{array}$ & Rutaceae & Lemon & Limbu & Tree & $\begin{array}{l}\text { Used mainly for culinary purposes and in } \\
\text { the preparation of beverages. Oil of } \\
\text { Lemon, used as carminative and for } \\
\text { flavouring liqueurs. Lemon juice is very } \\
\text { useful for scurvy. Fruit in the form of } \\
\text { pickle useful in hypertrophy of spleen. }\end{array}$ \\
\hline 20 & $\begin{array}{l}\text { Coleus amboinicus } \\
\text { (Lour.) Spreng }\end{array}$ & Lamiaceae & $\begin{array}{l}\text { Cuban } \\
\text { oregano }\end{array}$ & Ajma & Herb & $\begin{array}{l}\text { Used for the treatment of coughs, sore } \\
\text { throats and nasal congestion, also for a } \\
\text { range of other problems such as } \\
\text { infections, rheumatism and flatulence }\end{array}$ \\
\hline 21 & $\begin{array}{l}\text { Cordia dichotoma } \\
\text { G.Forst. }\end{array}$ & Boraginaceae & $\begin{array}{l}\text { Indian } \\
\text { cherry }\end{array}$ & Gundo & Tree & $\begin{array}{l}\text { Dyspepsia, fever, Kernels: ring worms. } \\
\text { Leaf: ulcers, prolapse of uterus/vagina } \\
\text { and headache. Fruit: affection of Urinary } \\
\text { passages, diseases of lungs and spleen. } \\
\text { Plant: snakebite. Fruit: spleen and lungs } \\
\text { diseases, dry cough, chest and urethral } \\
\text { diseases, Chronic fever, lessening thirst, } \\
\text { scalding of urine, bad humours, joint } \\
\text { pains, throat burning. }\end{array}$ \\
\hline 22 & $\begin{array}{l}\text { Cordia sinensis } \\
\text { Lam. }\end{array}$ & Boraginaceae & $\begin{array}{l}\text { Grey-leaved } \\
\text { saucer berry }\end{array}$ & Gundi & Tree & $\begin{array}{l}\text { Decoction of the root and bark is used to } \\
\text { treat stomach disorders. Roots are boiled } \\
\text { and the decoction used for the treatment } \\
\text { of malaria. The roots are used to induce } \\
\text { abortion. Bark is astringent and is used } \\
\text { to prepare a gargle. The leaves are used } \\
\text { alone or in mixture with other medicinal } \\
\text { plants as a treatment against fever. }\end{array}$ \\
\hline 23 & $\begin{array}{l}\text { Crateva magna } \\
\text { (Lour.) DC }\end{array}$ & Capparaceae & $\begin{array}{l}\text { Large garlic } \\
\text { pear }\end{array}$ & Vayarno & Tree & $\begin{array}{l}\text { The fresh leaves are rubefacient and } \\
\text { tonic. They are applied as a tonic and } \\
\text { skin irritant against high fever. The bark } \\
\text { and roots are generally used against } \\
\text { various female disorders or as a tonic. } \\
\text { The root bark is used to treat urolithiasis. } \\
\text { The juice from the bitter stem or root } \\
\text { bark is used in decoction for stimulating } \\
\text { the appetite or as a digestive, as a } \\
\text { laxative against colic and as a febrifuge. }\end{array}$ \\
\hline 24 & $\begin{array}{l}\text { Dalbergia sissoo } \\
\text { Roxb. }\end{array}$ & Papilionaceae & $\begin{array}{l}\text { Indian } \\
\text { rosewood }\end{array}$ & Sisum & Tree & $\begin{array}{l}\text { The roots are astringent and } \\
\text { constipating. The leaves are bitter, stypic, } \\
\text { ophthalmic, digestive, constipating } \\
\text { anthelmintic, diuretic and stimulant. The } \\
\text { heartwood is astringent, abortifacient, } \\
\text { anthelmintic, vulnerary, anti- } \\
\text { inflammatory, aphrodisiac, } \\
\text { emmenagogue, antipyretic, depurative } \\
\text { and appetiser. The roots are useful in } \\
\text { dirhoea and dysentery. The leaves are } \\
\text { useful in gonorrhoea, menorrhoea, } \\
\text { excoriation, ophthalmopathy, dyspepsia, } \\
\text { colic, diarrhoea, dysentery, vomiting, } \\
\text { haemorrhoids and burning sensation. } \\
\text { The bark and heartwood are useful in } \\
\text { hyperdipsia, burning sensation, vomiting, } \\
\text { skin diseases, leprosy, leucoderma, } \\
\text { scabies, ulcers, dyspepsia, dysentery, } \\
\text { scalding of urine, syphilis, gastropathy, } \\
\text { helminthiasis, ophthalmopathy. } \\
\text { Amenorrhoea, dysmenorrhoea, hiccough, } \\
\text { bronchitis, sciatica, gout, inflammations, } \\
\text { intermittent fevers and vitiated } \\
\text { conditions of vata. }\end{array}$ \\
\hline 25 & Duranta erecta L. & Verbinaceae & Golden dew & Damyanti & Shrub & The plant is used in the treatment of \\
\hline
\end{tabular}




\begin{tabular}{|c|c|c|c|c|c|c|}
\hline & & & drops & & & $\begin{array}{l}\text { fevers, skin itches. The plant is used as an } \\
\text { insect repellant. }\end{array}$ \\
\hline 26 & $\begin{array}{l}\text { Euphorbia } \\
\text { tithymaloides L. }\end{array}$ & Euphorbiaceae & $\begin{array}{l}\text { Lady's } \\
\text { slipper } \\
\text { flower plant }\end{array}$ & $\begin{array}{l}\text { Vilati } \\
\text { Kharsani }\end{array}$ & Shrub & $\begin{array}{l}\text { Root powerful emetic, used in west } \\
\text { Indies under the name Ipecacuanha. } \\
\text { Latex enetic, and caustic, used in } \\
\text { venereal diseases; also applied to warts } \\
\text { and leucoderma patches. }\end{array}$ \\
\hline 27 & $\begin{array}{l}\text { Ficus amplissima } \\
\text { Rees. }\end{array}$ & Moraceae & Indian bat fig & Pipar & Tree & $\begin{array}{l}\text { Bark is used as a natural anti-diabetic } \\
\text { and anti-oxidant medicine, reducing } \\
\text { blood glucose levels. }\end{array}$ \\
\hline 28 & $\begin{array}{l}\text { Ficus benghalensis } \\
\text { L. }\end{array}$ & Moraceae & Banyan & Vad & Tree & $\begin{array}{l}\text { Plant: biliousness, ulcers, erysipelas, } \\
\text { vaginal complaints, fever, inflammations, } \\
\text { Vomiting, leucorrhoea. Root: gonorrhoea, } \\
\text { syphilis, biliousness, dysentery, } \\
\text { inflammations of liver. Root fibers: } \\
\text { gonorrhoea, obstinate vomiting, } \\
\text { diabetes, and haemoptysis. Bark: } \\
\text { Burning sensation, haemoptysis, } \\
\text { haemorrhages, diarrhoea, dysentery, } \\
\text { diabetes, enuresis, ulcers, skin diseases, } \\
\text { gonorrhoea, leucorrhoea, hyperdipsia. } \\
\text { Leaves: Ulcers, Leprosy, allergic } \\
\text { conditions of the skin, buming sensation, } \\
\text { abscesses. Buds: Diarrhoea, dysentery. } \\
\text { Milky juice: lessens inflammations, piles, } \\
\text { gonorrhoea, and diseases of nose. } \\
\text { Externally applied for pains and bruises } \\
\text { and in rheumatism and lumbago, applied } \\
\text { to soles of the. feet when cracked or } \\
\text { inflamed, also applied to teeth and gums } \\
\text { as a remedy for toothache. Fruits: } \\
\text { Refrigerant, tonic, pitta. Latex: Neuralgia, } \\
\text { rheumatism, lumbago, bruisies nastis, } \\
\text { ulorrhagia, ulitis, odontopathy, } \\
\text { haemorrhoids, gonorrhoea, } \\
\text { inflammations, cracks of the sole and } \\
\text { skin diseases. }\end{array}$ \\
\hline 29 & Ficus racemosa L. & Moraceae & Cluster fig & Umro & Tree & $\begin{array}{l}\text { Bark: Abortions. Leaves: Pitta, ulcers. } \\
\text { Tender fruits: pitta, diarrhoea, dyspepsia, } \\
\text { and hemorrhages. Ripe fruits: } \\
\text { Menorrhagia, haemoptysis. Latex: } \\
\text { aphrodisiac, haemorrhoids, diarrhoea. }\end{array}$ \\
\hline 30 & Ficus religiosa L. & Moraceae & Sacred fig & Piplo & Tree & $\begin{array}{l}\text { Plant parts: diseases of blood, vagina, } \\
\text { uterus, and leucorrhoea, burning } \\
\text { sensation, Gonorrhoea, Diarrhoea, } \\
\text { dysentery, haemorrhoids, gastrohelcosis. } \\
\text { Fruit: vomiting, digestion. Ripe fruit: } \\
\text { burning sensation, foul taste, biliousness, } \\
\text { blood and heart. Dried fruit: pulverized } \\
\text { asthma, fruitfulness in women. Root: } \\
\text { gout. Root bark: stomatitis, ulcers, } \\
\text { leucorrhoea, granulations, and lumbago. } \\
\text { Young root bark: bone fracture. } \\
\text { Powdered root bark: absorbent in } \\
\text { inflammatory swellings. Old leaves: } \\
\text { soaked in water stops vomiting. Bark: } \\
\text { Inflammatory swellings, burns. Leaves } \\
\text { and tender shoots: wounds, skin } \\
\text { diseases. Dried fruits: Asthma. Latex: } \\
\text { Neuralgia, inflammations and } \\
\text { hemorrhages. }\end{array}$ \\
\hline 31 & $\begin{array}{l}\text { Hibiscus rosa- } \\
\text { sinensis L. }\end{array}$ & Malvaceae & Shoe flower & Jasud & Shrub & $\begin{array}{l}\text { Buds: burning sensation, urinary } \\
\text { discharge, seminal weaknesses, piles, } \\
\text { uterine and vaginal discharge, promote } \\
\text { growth of foetus, cause vomiting and } \\
\text { intestinal worms. Roots: Cough, venereal }\end{array}$ \\
\hline
\end{tabular}




\begin{tabular}{|c|c|c|c|c|c|c|}
\hline & & & & & & $\begin{array}{l}\text { diseases, gonorrhoea, menorrhagia, } \\
\text { pruritus and fever. Leaves: Burning } \\
\text { sensation, hepatopathy, fatigue, } \\
\text { abscesses, expulsion of the placenta, skin } \\
\text { diseases, fever, constipation, pruritus. } \\
\text { Flowers: Kapha and pitta, boils, } \\
\text { inflammations, epilepsy, cerebropathy, } \\
\text { dysentery, haemorhoids, urethrorrhoea, } \\
\text { diabetes, bronchitis, emmenagoguge, } \\
\text { cardiac debility, haemoptysis, } \\
\text { menorrhagia, seminal weakness, skin } \\
\text { diseases, leprosy and pruritus. }\end{array}$ \\
\hline 32 & $\begin{array}{l}\text { Jasminum sambac } \\
\text { (L.) Sol }\end{array}$ & Oleaceae & Jui & Mogro & Shrub & $\begin{array}{l}\text { The leaves and flowers are considered } \\
\text { valuable as a lactifuge. Dried leaves } \\
\text { soaked in water and made into poultice } \\
\text { are used in indolent ulcers. }\end{array}$ \\
\hline 33 & $\begin{array}{l}\text { Justicia adhatoda } \\
\text { L. }\end{array}$ & Acanthaceae & Malabar nut & Ardusi & Shrub & $\begin{array}{l}\text { Plant: bronchitis, leprosy, blood } \\
\text { impurities, heart troubles, thirst, asthma, } \\
\text { fever, vomiting, loss of memory, } \\
\text { leucoderma, consumption, jaundice, } \\
\text { tumours, diseases of mouth. Root: } \\
\text { facilitates the expulsion of foetus, } \\
\text { strangury, leucorrhea with blood } \\
\text { discharges bronchitis, asthma, bilious } \\
\text { vomiting, sore eyes, fevers, gonorrhea. } \\
\text { Leaves: gonorrhea. Flowers: improving } \\
\text { blood circulation, lessen strangury, } \\
\text { jaundice. Fruit: bronchitis. Leaves and } \\
\text { Roots: for all sorts of cough. Juice of } \\
\text { leaves diarrhoea, dysentery. Fresh } \\
\text { flower: Ophthalmia. Root: powder: } \\
\text { malarial fever, treatment of cold and } \\
\text { cough, asthma, phthisis, diphtheria. }\end{array}$ \\
\hline 34 & $\begin{array}{l}\text { Kalanchoe } \\
\text { pinnata (Lam.) } \\
\text { Pers. }\end{array}$ & Crassulaceae & Life plant & Pannfuti & Herb & $\begin{array}{l}\text { Vitiated conditions of pitta and vata, } \\
\text { haematemesis. haemorrhoids, } \\
\text { menorrhagia, cuts and wounds, } \\
\text { discolourisations of the skin, boils, } \\
\text { sloughing, ulcers, opthalmia, burns, } \\
\text { scalds, corn, diarrhoea dysentery, } \\
\text { vomiting, acute inflammations. }\end{array}$ \\
\hline 35 & $\begin{array}{l}\text { Leucaena } \\
\text { leucocephala } \\
\text { (Lam.) de Wit }\end{array}$ & Mimosaceae & $\begin{array}{l}\text { Wild } \\
\text { tamarind }\end{array}$ & Liso baval & Tree & $\begin{array}{l}\text { A decoction of the root and bark is } \\
\text { abortifacient. The roasted seeds are } \\
\text { emollient. }\end{array}$ \\
\hline 36 & $\begin{array}{l}\text { Limonia } \\
\text { acidissima } \mathrm{L} .\end{array}$ & Rutaceae & Wood apple & Kothu & Tree & $\begin{array}{l}\text { Leaves are carminative, and astringent, } \\
\text { yield an essential oil. Fruits are tonic, } \\
\text { antiscorbutic, alexipharmic. Fruits are } \\
\text { used in constipation. }\end{array}$ \\
\hline 37 & $\begin{array}{l}\text { Mangifera indica } \\
\text { L. }\end{array}$ & Anacardiaceae & Mango & Keri & Tree & $\begin{array}{l}\text { Root and bark: Pitta, metrorrhagia. } \\
\text { colonorrhagia, Pneumorrhagia, } \\
\text { leucorrhoea, syphilis, wounds, ulcers, } \\
\text { vomiting, uteritis, diarrhoea, dysentery, } \\
\text { diptheria, rheumatism. Leaves: Kapha } \\
\text { and pitta, hiccough, hyperdipsia, burning } \\
\text { sensation, haemorrhages, haemoptysis, } \\
\text { haemorrhoids, wounds, ulcers, } \\
\text { diarrhoea, dysentery, pharyngopathy, } \\
\text { stomatopathy. Ash of burnt leaves: burns } \\
\text { and scalds. Flowers: Pitta, haemorrhoids, } \\
\text { haemoptysis, haemorrhages, wounds, } \\
\text { ulcers, anorexia. Unripe fruit: } \\
\text { Gastropathy, dyspepsia, pharyngopathy, } \\
\text { ulcers, dysentery, urethrorrhoea, } \\
\text { vaginopathy. Ripe fruit: Vata and pitta, } \\
\text { anorexia, dyspepsia, cardiopathy, } \\
\text { haemoptysis, haemorrhages, emaciation, } \\
\text { anaemia, debility. Seed kernel: diarrhea, }\end{array}$ \\
\hline
\end{tabular}




\begin{tabular}{|c|c|c|c|c|c|c|}
\hline & & & & & & $\begin{array}{l}\text { dysentery, haemorrhoids, haemorthages, } \\
\text { haemoptysis, ulcers, bruises, } \\
\text { leucorrhoea, menorrhagia, diabetes, } \\
\text { heartburn, vomiting. Leaves, bark, stem } \\
\text { and unripe fruit shows antibacterial } \\
\text { activity. }\end{array}$ \\
\hline 38 & $\begin{array}{l}\text { Manilkara } \\
\text { hexandra (Roxb.) } \\
\text { Dubard }\end{array}$ & Sapotaceae & $\begin{array}{l}\text { Ceylon iron } \\
\text { wood }\end{array}$ & Rayan & Tree & $\begin{array}{l}\text { The fruit is oleaginous, cooling, } \\
\text { indigestible, tonic, aphrodisiac. The fruit } \\
\text { is good for heart and cures biliousness, } \\
\text { useful in leprosy. The seeds cure ulcers } \\
\text { and opacities in the cornea. }\end{array}$ \\
\hline 39 & $\begin{array}{l}\text { Melia azedarach } \\
\text { L. }\end{array}$ & Meliaceae & $\begin{array}{l}\text { Chinaberry } \\
\text { tree }\end{array}$ & $\begin{array}{l}\text { Bakan } \\
\text { limdo }\end{array}$ & Tree & $\begin{array}{l}\text { The roots are acrid, bitter, astringent, } \\
\text { mildly heating, anodyne, depurative, } \\
\text { vulnerary, anti-septic, anthelmintic, } \\
\text { constipating, expectorant, febrifuge, anti- } \\
\text { periodic, urinary astringent, } \\
\text { emmenagogue and tonic. The leaves are } \\
\text { bitter, astringent, expectorant, } \\
\text { vermicidal, antilithic, diuretic, } \\
\text { emmenagogue and stomachic. The seeds } \\
\text { are bitter, expectorant, anthelmintic, } \\
\text { aphrodisiac. The flowers are astringent, } \\
\text { refrigerant, anodyne, stomachic, } \\
\text { Vermifuge, diuretic, emmenogogue, } \\
\text { deobstruant and alexipharmic. The seed } \\
\text { oil is laxative, anthelmintic, depurative, } \\
\text { maturant and tonic. The roots are useful } \\
\text { in vitiated conditions of diseases, vata, } \\
\text { sciatica, skin helminthiasis especially } \\
\text { tapeworm, asthma, Amenorrhoea, } \\
\text { dysmenorrhoea, chronic and } \\
\text { intermittent fever, burning sensation and } \\
\text { general debility. In excessive dose it is } \\
\text { emetic and purgative. The leaves are } \\
\text { useful in hysteria, leprosy, splenomegaly, } \\
\text { cough, bronchitis and scabies. The seeds } \\
\text { are useful in helminthiasis, typhoid fever, } \\
\text { pain in pelvic region. The flowers are } \\
\text { useful in cephalalgia, gastropathy, } \\
\text { verminosis, strangury and fever. The } \\
\text { seed oil is useful in hepatopathy, leprosy, } \\
\text { otalgia, splenomegaly and dermatopathy. }\end{array}$ \\
\hline 40 & $\begin{array}{l}\text { Mimusops elengi } \\
\text { L. }\end{array}$ & Sapotaceae & $\begin{array}{l}\text { Spanish } \\
\text { cherry }\end{array}$ & Borsali & Tree & $\begin{array}{l}\text { Bark: used as a gargle for odontopathy, } \\
\text { ulitis, ulemorrhagia. Tender stems: tooth } \\
\text { brushes, cystorrhoea, diarrhoea, } \\
\text { dysentery. Flowers: lotion for wound and } \\
\text { ulcers, cephalagia. Seeds: Constipation. }\end{array}$ \\
\hline 41 & $\begin{array}{l}\text { Moringa oleifera } \\
\text { Lam. }\end{array}$ & Moringaceae & Drumstick & Saragavo & Tree & $\begin{array}{l}\text { Vata and kapha, dyspepsia, anorexia, } \\
\text { verminosis, diarrhoea, colic, flatulence, } \\
\text { otalgia, paralysis, inflammations, } \\
\text { amenorrhoea, dysmenorrhoea, fever, } \\
\text { strangury, vesical and renal calculi, } \\
\text { ascites, opthamapathy, cough, asthma, } \\
\text { bronchitis, pectoral diseases, } \\
\text { splenomegaly, epilepsy, hysteria, } \\
\text { cardiopathy, abscess, pharyngodynia. } \\
\text { Bark: ascites, vitiated conditions of vata } \\
\text { and kapha, ringworm. Leaves: Scurvy, } \\
\text { vata and kapha, wounds, tumuors, } \\
\text { inflammations, antihelminthis. Seeds: } \\
\text { neuralgia, inflammations, intermitter } \\
\text { fever, opthamology. }\end{array}$ \\
\hline 42 & Morus alba L. & Moraceae & Mulberry & Shetur & Shrub & $\begin{array}{l}\text { Fruit is useful for sore throat, dyspepsia } \\
\text { and melancholia. Root bark used in } \\
\text { nervous disorders. }\end{array}$ \\
\hline
\end{tabular}




\begin{tabular}{|c|c|c|c|c|c|c|}
\hline 43 & $\begin{array}{l}\text { Muntingia } \\
\text { calabura L. }\end{array}$ & Muntingiaceae & Bird cherry & $\begin{array}{l}\text { Jamaikan } \\
\text { cherry }\end{array}$ & Tree & $\begin{array}{l}\text { Infusion of the flowers is valued as an } \\
\text { antispasmodic. It is taken to relieve } \\
\text { headache. Flowers are said to possess } \\
\text { antiseptic properties. }\end{array}$ \\
\hline 44 & $\begin{array}{l}\text { Murraya koenigii } \\
\text { (L.) Sprg. }\end{array}$ & Rutaceae & $\begin{array}{l}\text { Curry leaf } \\
\text { plant }\end{array}$ & $\begin{array}{l}\text { Mitho } \\
\text { Limbdo }\end{array}$ & Shrub & $\begin{array}{l}\text { The leaves and roots cure piles allay heat } \\
\text { of the body, thirst inflammation, itching } \\
\text { and useful in leucoderma and blood } \\
\text { disorders. Barks and roots are used to } \\
\text { cure eruptions and the bite of poisonous } \\
\text { animals. The green leaves are eaten raw } \\
\text { for the cure of dysentery; infusion is used } \\
\text { to stop vomiting. Juice of the rood is good } \\
\text { for the pain associated with kidney. The } \\
\text { fruit is useful in diarrhoea and dysentery. }\end{array}$ \\
\hline 45 & $\begin{array}{l}\text { Ocimum } \\
\text { tenuiflorum } \mathrm{L} .\end{array}$ & Lamiaceae & Holy basil & Tulsi & Herb & $\begin{array}{l}\text { The juice of leaves possesses diaphoretic, } \\
\text { antiperiodic, stimulating and expectorant } \\
\text { properties. Used in catarrh and } \\
\text { bronchitis, applied to the skin, in } \\
\text { ringworm and other cutaneous diseases } \\
\text { and dropped into the ear to relieve } \\
\text { earache. An infusion of the leaves is used } \\
\text { as a stomachic in gastric disorders of } \\
\text { children. A decoction of the root is given } \\
\text { as a diaphoretic in malarial fevers. The } \\
\text { seeds are mucilaginous and demulcent, } \\
\text { and are given in disorders of } \\
\text { genitourinary systems }\end{array}$ \\
\hline 46 & $\begin{array}{l}\text { Peltophorum } \\
\text { pterocarpum } \\
\text { (DC.) K. Heyne }\end{array}$ & Caesalpiniaceae & Copperpod & Tamraparni & Tree & $\begin{array}{l}\text { Different parts of this tree are used to } \\
\text { treat many diseases like stomatitis, } \\
\text { insomnia, skin troubles and constipation. } \\
\text { The traditional healers use the leaves in } \\
\text { the form of decoction for treating skin } \\
\text { disorders. Bark is used as medicine for } \\
\text { dysentery, as eye lotion, embrocation for } \\
\text { pains and sores. Stem infusion used in } \\
\text { dysentery, for gargles, tooth powder and } \\
\text { muscular pain. Flowers are used as an } \\
\text { astringent to cure or relieve intestinal } \\
\text { disorders after pain at childbirth, } \\
\text { sprains, bruises and swelling or as a } \\
\text { lotion for eye troubles, muscular pains } \\
\text { and sores. }\end{array}$ \\
\hline 47 & $\begin{array}{l}\text { Phoenix } \\
\text { dactylifera L. }\end{array}$ & Arecaceae & Date palm & Khajuri & Tree & $\begin{array}{l}\text { Fruits are edible, considered restorative } \\
\text { olcaginous, cardiotonic, fattening, } \\
\text { abdominal constipating, aphrodisiac, } \\
\text { good in heart complaints, vomiting, } \\
\text { wandering of mind, Loss of } \\
\text { consciousness. The central tender part is } \\
\text { used in gonorrhoea and gleet. The root is } \\
\text { used in tooth ache. }\end{array}$ \\
\hline 48 & $\begin{array}{l}\text { Phyllanthus } \\
\text { emblica L. }\end{array}$ & Euphorbiaceae & $\begin{array}{l}\text { Indian goose } \\
\text { berry }\end{array}$ & Amla & Tree & $\begin{array}{l}\text { Root bark is useful in ulcerative } \\
\text { stomatitis, gastrohelicosis. The leaves are } \\
\text { useful in conjunctivitis, inflammations, } \\
\text { dyspepsia, diarrhoea and dysentery. The } \\
\text { fruits are useful in vitiated conditions of } \\
\text { tridosha, diabetes, cough, asthma, } \\
\text { bronchitis, cephalagia, ophthalmopathy, } \\
\text { dyspepsia, colic, flatulence, hyperacidity, } \\
\text { peptic ulcer, erysipelas, skin diseases, } \\
\text { leprosy, haematemesis, inflammations, } \\
\text { anaemia, emaciation, hepatopathy, } \\
\text { jaundice, strangury, diarrhoea, } \\
\text { dysentery, haemorrhages, leucorrhoea, } \\
\text { menorrhagia, cardiac disoders, } \\
\text { intermittent fever and greyness of hair. }\end{array}$ \\
\hline
\end{tabular}




\begin{tabular}{|c|c|c|c|c|c|c|}
\hline 49 & $\begin{array}{l}\text { Pithecellobium } \\
\text { dulce (Roxb.) } \\
\text { Benth. }\end{array}$ & Mimosaceae & $\begin{array}{l}\text { Manilla } \\
\text { tamarind }\end{array}$ & Goras ambli & Tree & $\begin{array}{l}\text { A paste made from the leaves is applied } \\
\text { externally to treat muscular swellings } \\
\text { caused by some inflammations. Bark of } \\
\text { the root is a good remedy for diarrhoea } \\
\text { and dysentery. The bark is used } \\
\text { medicinally as a febrifuge. The fruit pulp } \\
\text { is taken orally to stop blood flow in case } \\
\text { of haemoptysis. The seed juice is inhaled } \\
\text { into the nostrils against chest congestion } \\
\text { and pulverised seeds are ingested for } \\
\text { internal ulcers. }\end{array}$ \\
\hline 50 & Plumeria rubra L. & Apocynaceae & $\begin{array}{l}\text { White } \\
\text { frangipani }\end{array}$ & Champo & Tree & $\begin{array}{l}\text { Root Bark: Ulcers, Pruritus, leprosy, } \\
\text { gastropathy. vata and kapha. Leaves: } \\
\text { inflammations. Milky juice: rubefacient in } \\
\text { rheumatism. }\end{array}$ \\
\hline 51 & $\begin{array}{l}\text { Pongamia pinnata } \\
\text { (L.) Pierre }\end{array}$ & Papilionaceae & $\begin{array}{l}\text { Indian beech } \\
\text { tree }\end{array}$ & Karanj & Tree & $\begin{array}{l}\text { Seeds oil is useful in skin diseases, } \\
\text { eczema. Root is used for treating } \\
\text { gonorrhea, cleaning gums, teeth, and } \\
\text { ulcers, and is also used in vaginal and } \\
\text { skin diseases. }\end{array}$ \\
\hline 52 & $\begin{array}{l}\text { Prosopis cineraria } \\
\text { (L.) Druce }\end{array}$ & Mimosaceae & Ghaf & Khijado & Tree & $\begin{array}{l}\text { The plant is reported to be astringent, } \\
\text { demulcent, and pectora. The flowers are } \\
\text { pounded, mixed with sugar and eaten } \\
\text { during pregnancy as a safeguard against } \\
\text { miscarriage. The ashes of the plant are } \\
\text { rubbed over the skin to remove hair. The } \\
\text { bark is considered to be anthelmintic, } \\
\text { refrigerant, and tonic. It is used for } \\
\text { treating asthma, bronchitis, dysentery, } \\
\text { leucoderma, leprosy, rheumatism, } \\
\text { scorpion stings, muscle tremors, piles, } \\
\text { and wandering of the mind. Smoke from } \\
\text { the leaves is suggested for eye troubles. } \\
\text { The seedpod is said to be astringent. }\end{array}$ \\
\hline 53 & $\begin{array}{l}\text { Psidium guajava } \\
\text { L. }\end{array}$ & Myrtaceae & Guava & Jamphal & Tree & $\begin{array}{l}\text { Roots: haemorrhages, diarrhoea, } \\
\text { dysentery, ulcers, gingivitis, proctoptosis, } \\
\text { vomiting. Leaves: Wounds, ulcers, } \\
\text { cholera, diarrhoea, vomiting, nephritis, } \\
\text { cachexia, vata, epilepsy, odontalgia, gum } \\
\text { boils. Flowers: bronchitis, } \\
\text { opthalmodynia, colic, ulemorrhagia. } \\
\text { Fruits: Pitta, dipsia, burning sensation, } \\
\text { colic, ulemorrhagia, diarrhoea, } \\
\text { dysentery, debility. }\end{array}$ \\
\hline 54 & $\begin{array}{l}\text { Punica granatum } \\
\text { L. }\end{array}$ & Lythraceae & Pomegranate & Dadam & Shrub & $\begin{array}{l}\text { Root and stem bark: Tapeworm } \\
\text { infection, vomiting. Flowers: Vomiting, } \\
\text { pitta, opthalmodynia, ulcers, } \\
\text { pharyngodynia, hydrocele. Fruits: } \\
\text { Anaemia, hyperdipsia, pharyngodynia, } \\
\text { opthalmodynia, pectoral diseases, } \\
\text { splenopathy, bronchitis, otalgia. Fruit } \\
\text { rind: dysentery. diarthoea, and } \\
\text { gastralgia. Seeds: vomiting, } \\
\text { opthalmodynia, pitta, scabies, } \\
\text { hepatopathy, splenopathy. }\end{array}$ \\
\hline 55 & Ruellia tuberosa L. & Acanthaceae & $\begin{array}{l}\text { Snapdragon } \\
\text { root }\end{array}$ & Fatakadi & Herb & $\begin{array}{l}\text { Used for the treatment of stones in the } \\
\text { bladder. A decoction of the leaves is } \\
\text { given in chronic bronchitis }\end{array}$ \\
\hline 56 & $\begin{array}{l}\text { Salvadora persica } \\
\text { L. }\end{array}$ & Salvadoraceae & Meswak & Piludi & Tree & $\begin{array}{l}\text { The root bark is used to relieve } \\
\text { splenalgia. The stem bark is useful in } \\
\text { asthma, bronchitis, and cough, vitiated } \\
\text { condition of vata, strangury, painful } \\
\text { tumors, scurvy, constipation, verminosis } \\
\text { and haemorrhoids. The shoots and leaves } \\
\text { are useful in all types of poisons, cough }\end{array}$ \\
\hline
\end{tabular}




\begin{tabular}{|c|c|c|c|c|c|c|}
\hline & & & & & & $\begin{array}{l}\text { and bronchitis. The fruits are stomachic, } \\
\text { purgative and digestive. Tender twigs are } \\
\text { used as toothbrush. }\end{array}$ \\
\hline 57 & $\begin{array}{l}\text { Senna auriculata } \\
\text { (L.) Roxb. }\end{array}$ & Caesalpiniaceae & $\begin{array}{l}\text { Matura tea } \\
\text { tree }\end{array}$ & Aval & Shrub & $\begin{array}{l}\text { The root is used in decoctions against } \\
\text { fevers, diabetes, diseases of urinary } \\
\text { system and constipation. The leaves have } \\
\text { laxative properties. The dried flowers } \\
\text { and flower buds are used as a substitute } \\
\text { for tea in case of diabetes patients. The } \\
\text { seeds are used in ophthalmia. }\end{array}$ \\
\hline 58 & $\begin{array}{l}\text { Senna siamea } \\
\text { (Lam.) Irwin et } \\
\text { Barneby }\end{array}$ & Caesalpiniaceae & Kassod tree & Kasheed & Tree & $\begin{array}{l}\text { Fruit is used to charm away intestinal } \\
\text { worms and to prevent convulsions in } \\
\text { children. The heartwood is said to be a } \\
\text { laxative, and a decoction is used against } \\
\text { scabies. }\end{array}$ \\
\hline 59 & $\begin{array}{l}\text { Syzygium cumini } \\
\text { (L.) Skeels. }\end{array}$ & Myrtaceae & Black plum & Jamboo & Tree & $\begin{array}{l}\text { The bark is useful in diabetes, } \\
\text { leucorrhoea, stomachaigia, fever, } \\
\text { gastropathy, strangury and } \\
\text { dermatopathy. The tender leaves are } \\
\text { used for vomiting. The leaves are used } \\
\text { for strengthnening the teeth and gums. } \\
\text { The fruits and seeds are used in diabetes, } \\
\text { diarrhoea, pharyngitis, splenopathy, } \\
\text { urethrorrhoea and ring worm. }\end{array}$ \\
\hline 60 & $\begin{array}{l}\text { Syzygium jambos } \\
\text { L. (Alston) }\end{array}$ & Myrtaceae & Rose apple & $\begin{array}{l}\text { Gulab } \\
\text { jamboo }\end{array}$ & Tree & $\begin{array}{l}\text { The bark is astringent, bitter, sweet, } \\
\text { haemostatic, depurative, vulnerary, anti } \\
\text { diarrhoeal and anthelmintic. The fruits } \\
\text { sweet and aromatic and are edible. Bark } \\
\text { is useful in gout, haemorrhages, syphilis, } \\
\text { leprosy, dermatopathy, diarrhoea, colic, } \\
\text { helminthiasis, wound, ulcers, stomatitis } \\
\text { and vitiated conditions of 'pitta'. }\end{array}$ \\
\hline 61 & $\begin{array}{l}\text { Tabernaemontana } \\
\text { divaricata R.Br. ex } \\
\text { Roem. \& Schult. }\end{array}$ & Apocynaceae & $\begin{array}{l}\text { Crape } \\
\text { jasmine }\end{array}$ & Tagar & Shrub & $\begin{array}{l}\text { Crude extract used against infectious } \\
\text { diseases such as syphilis, leprosy, and } \\
\text { gonorrhoea, as well as its antiparasitic } \\
\text { action against worms, dysentery, } \\
\text { diarrhoea, and malaria. }\end{array}$ \\
\hline 62 & $\begin{array}{l}\text { Tamarindus } \\
\text { indica } \mathrm{L} .\end{array}$ & Caesalpiniaceae & $\begin{array}{l}\text { Tamarind } \\
\text { tree }\end{array}$ & Ambli & Tree & $\begin{array}{l}\text { The root bark is useful in diarrhoea, } \\
\text { asthama, Amenorrhoea, gingivitis and } \\
\text { ulcers. The leaves are useful in vitiated } \\
\text { conditions of vata, swellings, fever, } \\
\text { scalding of urine, gastropathy. } \\
\text { helminthiasis, wounds, ulcers, jaundice, } \\
\text { scabies, tumours, ringworms, boils, small } \\
\text { pox, otalgia and conjunctivitis. The fruits } \\
\text { are useful in gastropathy, bilious } \\
\text { vomiting, dhatura poisoning, alcoholic } \\
\text { intoxication, dypsia, scabies, pharyngitis, } \\
\text { poisoning, stomatitis, constipation, } \\
\text { haemorrhoids, ophthalmopathy. The } \\
\text { seeds are useful in stomachalgia, } \\
\text { diarrhoea, dysentery, dipsia, burning } \\
\text { sensation, haematuria, giddiness, vertigo, } \\
\text { hepatopathy, inflammations, chronic } \\
\text { ulcers, abcess, haemorrhoids, } \\
\text { vaginopathy, metroptosis, diabetes and } \\
\text { general debility. }\end{array}$ \\
\hline 63 & $\begin{array}{l}\text { Tecoma stans (L.) } \\
\text { Juss. ex Kunth }\end{array}$ & Bignoniaceae & $\begin{array}{l}\text { Yellow } \\
\text { trumpet }\end{array}$ & Pili vasant & Shrub & $\begin{array}{l}\text { Used for treatment of diabetes, digestive } \\
\text { problems, control of yeast infections, as } \\
\text { powerful diuretic, vermifuge and tonic. }\end{array}$ \\
\hline 64 & $\begin{array}{l}\text { Tecomella } \\
\text { undulata }(\mathrm{Sm}) \\
\text { Seem }\end{array}$ & Bignoniaceae & Desert teak & Ragatrohido & Tree & $\begin{array}{l}\text { The bark is used for syphilis. Bark given } \\
\text { internally on broken bones. }\end{array}$ \\
\hline
\end{tabular}




\begin{tabular}{|c|c|c|c|c|c|c|}
\hline 65 & $\begin{array}{l}\text { Terminalia arjuna } \\
\text { (Roxb.) Wight \& } \\
\text { Arn. }\end{array}$ & Combretaceae & Arjun tree & Arjun sadad & Tree & $\begin{array}{l}\text { It is useful in fractures, ulcers, } \\
\text { urethrorrhoea, leucorrhoea, diabetes, } \\
\text { vitiated conditions of pitta, anaemia, } \\
\text { cardiopathy, hyperhidrosis, fatigue, } \\
\text { asthma, bronchitis, tumours, otalgia, } \\
\text { inflammations, dysentery, internal and } \\
\text { external haemorrhages and hypotension. }\end{array}$ \\
\hline 66 & $\begin{array}{l}\text { Terminalia } \\
\text { bellirica (Gaertn.) } \\
\text { Roxb. }\end{array}$ & Combretaceae & $\begin{array}{l}\text { Belleric } \\
\text { myrobalan }\end{array}$ & Baheda & Tree & $\begin{array}{l}\text { The bark is useful in leucoderma. The } \\
\text { fruits are useful in vitiated conditions of } \\
\text { vata and pitta, cough, bronchitis, } \\
\text { pharyngitis, insomnia, dropsy, dyspepsia, } \\
\text { flatulence, dipsia, vomiting, } \\
\text { haemonrhages, ophthalmopathy, } \\
\text { strangury, splenomegali, cephalalgia, } \\
\text { skin diseases, leprosy, fever, ulcer and } \\
\text { general debility. The oil obtained from } \\
\text { the seeds is useful in dyspepsia, skin } \\
\text { diseases, leucoderma and greyness of } \\
\text { hairs. }\end{array}$ \\
\hline 67 & $\begin{array}{l}\text { Terminalia } \\
\text { catappa L. }\end{array}$ & Combretaceae & $\begin{array}{l}\text { Indian } \\
\text { almond }\end{array}$ & Badam & Tree & $\begin{array}{l}\text { Fruit is useful inbiliousness, bronchitis } \\
\text { and bowels. Juice of the leaves is used in } \\
\text { the preparation of the ointment for } \\
\text { scabies, laprosy and other cutaneous } \\
\text { diseases and also useful in headache and } \\
\text { colic. The root bark is given in dysentery } \\
\text { and diarrhoea. The bark cures bilious } \\
\text { fevers. }\end{array}$ \\
\hline 68 & $\begin{array}{l}\text { Terminalia } \\
\text { chebula Retz. }\end{array}$ & Combretaceae & $\begin{array}{l}\text { Chebulic } \\
\text { myrobalan }\end{array}$ & Harde & Tree & $\begin{array}{l}\text { They are useful in vitiated conditions of } \\
\text { tridoshas, wounds, ulcers. inflammations, } \\
\text { hepatopathy, gastropathy, anorexia, } \\
\text { helminthiasis, flatulence, haemorrhoids, } \\
\text { jaundice, hepatopathy, splenopathy, } \\
\text { pharyngodynia, hiccough, cough, } \\
\text { uropathy and general debility. }\end{array}$ \\
\hline 69 & $\begin{array}{l}\text { Thespesia } \\
\text { populnea (L.) Sol. } \\
\text { ex Correa }\end{array}$ & Malvaceae & $\begin{array}{l}\text { Indian tulip } \\
\text { tree }\end{array}$ & $\begin{array}{l}\text { Paras } \\
\text { peeplo }\end{array}$ & Tree & $\begin{array}{l}\text { It is useful in dermatopathy such as } \\
\text { scabies, psoriasis, ringwomm and } \\
\text { guineaworm, leprosy, urethritis, } \\
\text { gonorrhoea, haemorhoids, } \\
\text { haemorrhages, haemotysis, } \\
\text { inflammations, wounds, ulcers, } \\
\text { diarrhoea, dysentery, diabetes, cholera, } \\
\text { ascites, dyspnea, cough, asthama, } \\
\text { catarrah, and vitiated conditions of pitta. } \\
\text { The bark and fruits possess more } \\
\text { curative properties. }\end{array}$ \\
\hline 70 & Vitex negundo L. & Verbinaceae & Chaste tree & Nagod & Tree & $\begin{array}{l}\text { The roots are useful in vitiated } \\
\text { conditions of vata, cephalalgia, otalgia, } \\
\text { arthritis, inflammations, dyspepsia, colic, } \\
\text { verminosis, flatulence, dysentery, } \\
\text { uropathy, wounds, ulcers, bronchitis, } \\
\text { cough, malarial fever, heamorrhoids, } \\
\text { dysmannorhoea, leprosy, dermatopathy, } \\
\text { ophathalmopathy and general debility. } \\
\text { The leaves are useful in vitiated } \\
\text { conditions of vata, cephalalgia, sprains, } \\
\text { orchitis, gout, splenohepatomegaly, } \\
\text { Otorrhoea, inflammations and ulcers. } \\
\text { The bark is useful in vitiated conditions } \\
\text { of vata, odontalgia, verminosis and } \\
\text { ophthalmopathy. }\end{array}$ \\
\hline 71 & $\begin{array}{l}\text { Volkameria } \\
\text { inermis L. }\end{array}$ & Verbinaceae & Glory bowee & $\begin{array}{l}\text { Vilayati } \\
\text { mendi }\end{array}$ & Shrub & $\begin{array}{l}\text { The juice of the leaves has much } \\
\text { reputation to bring down the fever. }\end{array}$ \\
\hline
\end{tabular}


Table: 2 Distribution of plant species according to their family.

\begin{tabular}{|c|c|}
\hline Family & No. of species \\
\hline Caesalpiniaceae & 7 \\
\hline Apocynaceae & 6 \\
\hline Mimosaceae & 5 \\
\hline Moraceae & 5 \\
\hline Combretaceae & 4 \\
\hline Rutaceae & 4 \\
\hline Myrtaceae & 3 \\
\hline Papilionaceae & 3 \\
\hline Verbinaceae & 3 \\
\hline Acanthaceae & 2 \\
\hline Bignoniaceae & 2 \\
\hline Boraginaceae & 2 \\
\hline Euphorbiaceae & 2 \\
\hline Lamiaceae & 2 \\
\hline Malvaceae & 2 \\
\hline Meliaceae & 2 \\
\hline Sapotaceae & 2 \\
\hline Amaranthaceae & 1 \\
\hline Anacardiaceae & 1 \\
\hline Annonaceae & 1 \\
\hline Arecaceae & 1 \\
\hline Bombacaceae & 1 \\
\hline Capparaceae & 1 \\
\hline Crassulaceae & 1 \\
\hline Lythraceae & 1 \\
\hline Moringaceae & 1 \\
\hline Muntingiaceae & 1 \\
\hline Oleaceae & 1 \\
\hline Poaceae & 1 \\
\hline Salvadoraceae & 1 \\
\hline Simaroubaceae & 1 \\
\hline Solanaceae & 1 \\
\hline
\end{tabular}

The Study also revealed that the presence of medicinally important trees and shrubs in the study area can be useful for the treatment of various ailments (Table 1). Mostly all the documented species have some therapeutic efficacies as shown in Table 1.9,10 These important plant species found in the Miyawaki plantation is enrich the vegetation as well as making the healthy and pleasant environment, helps to relieve stress and renew the spirits by providing calm and comfortable surroundings. These native forests have many functions and services such as disaster prevention and mitigation as well as air and water purification, and the blocking of sound, wind and dust.

\section{CONCLUSION}

The present work is the output of continuous field study and 71 plant species belonging to 32 families were recorded. According to the analysis of the habit, trees are dominant as compared to herbs and shrubs. The most dominant families were Caesalpiniaceae and Apocynaceae while genera point of view Ficus and Terminalia were dominant. Most of the plants documented in the present study showed some ethnobotanical and/or pharmacological significance. The present study can serve basis for further work focusing on recorded plant species for phytochemical and pharmacological importance with active metabolite capable of broadening the sources of new herbal drugs.

\section{Conflict of interest statement}

We declare that we have no conflict of interest.

\section{Acknowledgement}

The authors are grateful to Saurashtra University, Rajkot, Gujarat, India for providing an opportunity to carryout study in Miyawaki plantation and necessary supports in order to complete the study. The authors are also grateful to Sadbhavna Vrudhashram, an NGO actively working for increasing green cover and such plantations in the local and surrounding area of Rajkot.

\section{REFERENCES}

1. Miyawaki A. Entwicklung der Unweltschutz-Pflanzungen und Ansaaten in Japan. In: Tuxen R, editor. Sukuzessionsforschung Bericht uber das Internationale Symposium der Internationalen Vereinigung fur Vegetations-Kunde. Vaduz, Cramer; 1975. p 237-254.

2. Miyawaki A. Energy policy and green environment on the base of ecology. In: Smith RA, Smith CB, editors. Fazzolage. Beyond the Energy Crisis Opportunity and Challenge. Oxford and New York; 1981. p. 581-587.

3. Miyawaki A, Restoration of urban green environments based on the theories of vegetation ecology. Ecological Engineering. 1998; 11(1-4):157-165.

4. Miyawaki A. A Philosophical Basis for Restoring Ecologically Functioning Urban Forests: Current Methods and Results. In: Carreiro MM, Song YC, Wu J, editors. Ecology, Planning, and Management of Urban Forests. Springer, New York; 2008. p. 187-196.

5. Miyawaki A, Fujiwara K, Box EO, Toward harmonious green urban environments in Japan and other countries. Bulletin, Institute of Environmental Science and Technology, Yokohama National University. 1987; 14:67-82.

6. Miyawaki A, Golley FB, Forest reconstruction as ecological engineering. Ecological Engineering. 1993; 2(4):333-345.

7. Shah GL. The flora of Gujarat State. Vol. I and II, Sardar Patel University, Vallabh Vidhyanagar; 1978.

8. Cooke T. The flora of Bombay Presidency. Vol. I-III, B.S.I Calcutta (reprinted); 1958.

9. Anjaria J, Parabia M, Dwivedi S. Ethnovet Heritage Indian Ethnoveterinary Medicines. An overview, $1^{\text {st }}$ ed., Pathik enterprise, Ahmedabad, India; 2002.

10. Sriram S, Patel MA, Patel KV, Punjani NH. Compendium on Medicinal Plants. Gujarat Agricultural University, Ahmedabad; 2004. 